\title{
Whirling disease: host specificity and interaction between the actinosporean stage of Myxobolus cerebralis and rainbow trout Oncorhynchus mykiss
}

\author{
M. El-Matbouli ${ }^{1,2, *}$, R. W. Hoffmann ${ }^{2}$, H. Schoel ${ }^{3}$, T. S. McDowell ${ }^{1}$, R. P. Hedrick ${ }^{1}$ \\ ${ }^{1}$ Department of Medicine and Epidemiology, School of Veterinary Medicine, University of California, Davis, California 95616, USA \\ ${ }^{2}$ Institute of Zoology, Fish Biology and Fish Diseases, University of Munich, Kaulbachstr. 37, D-80539 Munich, Germany \\ ${ }^{3}$ Institute of Tropical Medicine and Parasitology, University of Munich, Leopoldstr. 5, D-80539 Munich, Germany
}

\begin{abstract}
Scanning electron microscopic studies were conducted on rainbow trout Oncorhynchus mykiss in the first $60 \mathrm{~min}$ after their exposure to the triactinomyxon spores of Myxobolus cerebralis. The results demonstrated that as early as 1 min post exposure the whole process, from the attachment of the triactinomyxon spores to the complete penetration of their sporoplasm germs, had occurred. The triactinomyxon spores sought out the secretory openings of mucous cells of the epidermis, the respiratory epithelium and the buccal cavity of trout and used them as portals of entry. Exposure experiments of the triactinomyxon spores of $M$. cerebralis to non-salmonid fish, such as goldfish Carassius auratus, carp Cyprinus carpio, nose Chondrostoma nasus, medaka Oryzias latipes, guppy Poecilia reticulata and also the amphibian tadpole Rana pipiens as well as to rainbow trout fry indicated a specificity for salmonids. Attempts to activate the triactinomyxon spores by exposure to mucus prepared from cyprinid and salmonid fish showed no significant differences from those conducted in tap water. The results suggest that the simultaneous presence of both mechano- and chemotactic stimuli was required for finding the salmonid fish host.
\end{abstract}

KEY WORDS: Myxobolus cerebralis . Triactinomyxon · Host specificity - Whirling disease

\section{INTRODUCTION}

Whirling disease (WD) is an economically devastating parasitic disease of salmonid fish, especially rainbow trout Oncorhynchus mykiss, caused by the triactinomyxon stage of Myxobolus cerebralis. It is typically a chronic disease that can cause high mortalities in fry and fingerlings of hatchery-reared and recently also feral rainbow trout (El-Matbouli et al. 1992, Hedrick et al. 1998). M. cerebralis has a complex, 2-host life cycle, beginning when waterborne triactinomyxon stages, released from the infected oligo-

-Address for correspondence: Department of Medicine and Epidemiology, School of Veterinary Medicine, University of California, Davis, California 95616, USA.

E-mail: melmatbouli@ucdavis.edu chaetes Tubifex tubifex, contact a susceptible trout Upon contact, the triactinomyxon spores attach to the fish and release their sporoplasms into the epidermis (Markiw 1989, El-Matbouli et al. 1995). Sporoplasms that penetrate begin multiplication and migration via peripheral nerves and the central nervous system, where by they reach the cartilage and further multiply. Approximately $50 \mathrm{~d}$ post infection, sporogenesis begins and, after a further proliferation phase, a large number of $M$. cerebralis spores are formed in the cartilage of infected fish. $M$. cerebralis spores are released into the aquatic environment only when infected fish die and autolyse, or when they are consumed and excreted by predators (El-Matbouli \& Hoffmann 1991). In both cases, spores released into the water can be ingested by the oligochaete $T$. tubifex, where they develop intercellularly in the intestine. Development through 
4 phases (schizogony, gametogony, gametogamy and sporogony) over a period of 3 mo gives rise to the actinosporean triactinomyxon. This is the only stage infectious for salmonid fish (El-Matbouli \& Hoffmann 1998).

The transcontinental spread of WD and its economic importance has increased with the worldwide development of salmonid farming and trade in live or frozen salmonid fish. Now WD has a worldwide distribution in at least 21 countries where rainbow trout have been introduced (Hoffman 1990). In addition to known effects on farmed trout, negative impacts of WD on wild trout populations have been reported (Nehring \& Walker 1996).

The purpose of this study was to investigate by scanning electron microscopy the interaction between triactinomyxon stages of Myxobolus cerebralis and rainbow trout fry during the first $10 \mathrm{~min}$ post exposure. In further experiments the host specificity of the triactinomyxon stages of $M$. cerebralis and the mechanisms that influence the interaction between the triactinomyxon spores and the fish host were studied.

\section{MATERIAL AND METHODS}

Collection of Myxobolus cerebralis spores. Rainbow trout, naturally infected with $M$. cerebralis, showing clinical signs of WD were used as spore sources. Spore-bearing heads of 30 rainbow trout were immersed in water at $40^{\circ} \mathrm{C}$ for 15 min to facilitate the isolation of skeletal parts. These were cut into 0.5-1.0 mm pieces with electrical scissors and mechanically disrupted by Ultra Turrax ${ }^{*}$, then suspended in tap water and sequentially passed through screens with mesh sizes of $1000,500,250$ and $100 \mu \mathrm{m}$. The final filtrate was centrifuged and the resulting pellets were resuspended in tap water. $M$. cerebralis spores were enumerated by counting in a hemocytometer.

Production and enrichment of triactinomyxon spores. Actinosporean-free oligochaetes (100 g) were placed in a $7 \mathrm{l}$ glass aquarium with sterilized mud as a substrate. A flow of tap water was supplied for $2 \mathrm{~d}$ to allow the oligochaetes to burrow into the mud. Afterwards water was drained down to about $10 \mathrm{~cm}$ above the mud just prior to adding the enriched spores of Myxobolus cerebralis to the aquarium. On average, each oligochaete worm was exposed to about $400 \mathrm{M}$. cerebralis spores. After $24 \mathrm{~h}$, a gentle flow of water was provided at a rate of 5 to $10 \mathrm{ml} \mathrm{min}{ }^{-1}$. Water temperature was $13 \pm 2^{\circ} \mathrm{C}$.

Production of waterborne triactinomyxon spores was detectable about $90 \mathrm{~d}$ post exposure. At $120 \mathrm{~d}$ post exposure the waterborne triactinomyxon spores (Fig. 1) were collected every 2 to $3 \mathrm{~d}$ by filtering $75 \%$ of the aquarium water through a $20 \mu \mathrm{m}$ mesh screen.
Exposure of rainbow trout fry to waterborne triactinomyxon spores. Collected waterborne triactinomyxon spores were immediately exposed to thirty 3-4 wk old specific-pathogen-free (SPF) rainbow trout fry. Exposure doses were about 10000 waterborne triactinomyxon spores per fish. Water volume was $1000 \mathrm{ml}$ for the first hour post exposure. Two fish were sampled every minute for the first $10 \mathrm{~min}$ post exposure. Fish were euthanized with chlorobutanol $(1,1,1$ trichloro-2-methyl-2-propanol, $0.1 \mathrm{~g} \mathrm{l}^{-1}$ water), then whole fish, without necropsy, were fixed in $1.5 \%$ Sorensen's-phosphate-buffered glutaraldehyde $(\mathrm{pH}$ $7.4)$ and prepared for scanning electron microscopy as follows: specimens were rinsed 3 times, each time for 20 min in Sorensen's phosphate buffer ( $\mathrm{pH} 7.4)$, dehydrated in a graded acetone series of 10,30 , and $50 \%$ for 10 min each, then $70,80,90$, and $95 \%$ for $1 \mathrm{~h}$ each and finally overnight in $100 \%$ acetone. The specimens were then processed in a critical-point dryer (Balzers Union CPD 020), placed on stubs, sputter-coated with approximately $12 \mathrm{~nm}$ of gold and examined with a Zeiss digital scanning electron microscope (DSM 950).

Host specificity of the triactinomyxon stage of $\mathbf{M y x o}$ bolus cerebralis. Trial 1: Four fish species $(2-4 \mathrm{~cm})$, goldfish Carassius auratus, carp Cyprinus carpio, nose Chondrostoma nasus and rainbow trout fry as exposure controls, were used for this experiment. For each species, 10 fish were placed in a container in water at an appropriate temperature of $13 \pm 2^{\circ} \mathrm{C}$. Water volume was about $1000 \mathrm{ml}$. The fish in all 4 containers were exposed to freshly harvested waterborne triactinomyxon spores. Each fish in every container was exposed to an average of 10000 waterborne triactinomyxon spores. Exposure in this small water volume was maintained for $3 \mathrm{~h}$. Fish were then transferred to $50 \mathrm{l}$ glass aquaria supplied with tap water. All the water from each container in which fish were exposed to the triactinomyxon spores was filtered through a $20 \mu \mathrm{m}$ mesh screen. Retained triactinomyxon spores were examined immediately for morphological changes. One fish from each species was removed 10 , 20 , and 30 min after contact with triactinomyxon spores. Fish were anaesthetized, cut sagitally into 2 halves and then fixed in $5 \%$ buffered formalin and embedded in Historesin ${ }^{\circ}$. Sections were stained with $H \& E$ and Giemsa's solutions. The remaining fish were checked twice a week for clinical signs. For detection of Myxobolus cerebralis infection, all fish were necropsied after anaesthetizing $140 \mathrm{~d}$ post exposure to triactinomyxon spores. Tissue samples from all parenchymatic organs and the cranium were prepared for histological examination as described above

Trial 2: Two non-salmonid fish, guppy Poecilia reticulata and medaka Oryzias latipes, the amphibian tadpole Rana pipiens and rainbow trout fry were used 
in this trial. Guppies and tadpoles were purchased from a commercial pet supplier and the medakas were from a laboratory colony. In 4 separate containers, 6 guppies ( $2 \mathrm{~cm}$ and $0.5 \mathrm{~g}), 6$ medaka $(3 \mathrm{~cm}$ and $0.5 \mathrm{~g}) ;$ 6 tadpole ( $4 \mathrm{~cm}$ and $2 \mathrm{~g}$ ) and 6 rainbow trout fry $(2 \mathrm{~cm}$ and $0.2 \mathrm{~g}$ ) were exposed to freshly collected triactinomyxon spores of Myxobolus cerebralis with a dose of 30000 spores ind.$^{-1}$ in $2000 \mathrm{ml}$ of $15^{\circ} \mathrm{C}$ well water. After $3 \mathrm{~h}$, fish or tadpoles were transferred into fresh well water. In another 4 containers, the same numbers of fish and tadpoles were transferred and held without adding triactinomyxon spores, as a control. After 2, 24 and $60 \mathrm{~h}$ post exposure 2 fish as well as tadpoles were taken from each of the 8 containers and fixed in Davidson's solution for standard histological examinations as described in Trial 1. This experiment was conducted 2 times.

Interaction between the triactinomyxon stages of Myxobolus cerebralis and fish components. In the first experiment, 8 actinosporea-free individuals of carp $(5-7 \mathrm{~cm})$, goldfish $(4-5 \mathrm{~cm})$ nose $(6-8 \mathrm{~cm})$ and rainbow trout $(9-10 \mathrm{~cm})$ were euthanized and rinsed immediately with tap water. The mucus from each group was wiped from the epidermis with a scalpel and collected in petri dishes. The mucus of each group was dissolved in $20 \mathrm{ml}$ tap water and filtered through a $500 \mu \mathrm{m}$ screen to remove fish scales. Directly afterwards, 10000 freshly harvested triactinomyxon spores were transferred to each petri dish containing the mucous suspension. The same number of triactinomyxon spores was added to a petri dish with $20 \mathrm{ml}$ tap water without mucus as a control. All petri dishes were held at $14 \pm$ $1^{\circ} \mathrm{C}$. To determine the effect of the mucus from each fish group on the triactinomyxon spores, a $1 \mathrm{ml}$ suspension from each of the 5 petri dishes was removed after 3,6 and 9 h post exposure. The percentage of empty spore shells without sporoplasm cells and those with extruded polar filaments were counted. This experiment was conducted 3 times.

In the second experiment, the dorsal, caudal, and pectoral fins of 5 euthanized SPF rainbow trout $(3-4 \mathrm{~cm})$ were cut and transferred to a petri dish containing 50000 triactinomyxon spores in $20 \mathrm{ml}$ tap water. Three hours post exposure, the fins were removed and fixed in $5 \%$ formalin, then prepared for histological examination as described above.

In the third experiment 3 containers were used, each containing 5 rainbow trout fry $(2-3 \mathrm{~cm})$ in $500 \mathrm{ml}$ water. In the first and second container, fish were killed by cervical severance and by overdoses with $500 \mathrm{ppm}$ benzocaine respectively and then exposed to freshly collected triactinomyxon spores (30000 ind. ${ }^{-1}$ ) for $3 \mathrm{~h}$. Fish in the third container were kept alive and exposed to the same number of triactinomyxons as a control. After $3 \mathrm{~h}$ post exposure the fish from each group were fixed in formalin and then prepared for histological examination as described above.

\section{RESULTS}

Scanning electron microscopy of the triactinomyxon of Myxobolus cerebralis revealed several properties of these spores. The 3 valves of the shell were connected in 3 prominent sutural ridges which could be followed down from the apical region (Fig. 2) to the branching point of the style (Fig. 3). These ridges were sackshaped and stitched laterally 3 times. Apically, the 3 sutures of the shell valves formed a $Y$-shape, leaving 3 apertures $620 \mathrm{~nm}$ in diameter at their intersection for polar filaments to discharge (Fig. 2). In all 3 apertures, the tips of the 3 polar capsules, were visible. Extruded polar filaments (Fig. 4) were $50 \mathrm{~nm}$ in diameter. During the preparation of the specimens, some spores were broken below the 3 polar capsules, making the sporoplasm cells conspicuous (Fig. 5). These were rounded (Fig. 6) with a $2.2 \mu \mathrm{m}$ diameter and embedded in the cytoplasm of the sporoplasm somatic cell.

\section{Interaction between the triactinomyxon spores of Myxobolus cerebralis and rainbow trout}

During the infection of rainbow trout fry in water containing the triactinomyxon stage of Myxobolus cerebralis, fish showed convulsive movements. At the same time, respiratory frequency increased, which was recognizable through the quick movements of the operculum. Simultaneously, the fish often jerked backwards. These spasms were observed in $10 \mathrm{~s}$ intervals for the first $15 \mathrm{~min}$ post exposure. Fish also secreted an increased amount of mucus into the water. After the fish were removed from the water containing the spores, water samples were taken and examined microscopically. The results indicated that 60 to $70 \%$ of the spores possessed no sporoplasm germs and that the polar capsules either had been extruded or were no longer present (Fig. 7). Simultaneously, there were occasionally naked sporoplasm packets in the water.

By scanning electron microscopy, interaction between the triactinomyxon spores of Myxobolus cerebralis and the rainbow trout fry was observed as early as 1 min post exposure. Simultaneously, triactinomyxon spores were found attached over the entire epidermis (Fig. 8) as well as in the area of the buccal cavity (Fig. 9) and the gills (Fig. 10). The spores sought out the opening of the mucous cells and used them as entranceways (Figs. 11, $12 \& 13$ ). Triactinomyxon spores observed 1 min post exposure had extruded their polar filaments and injected them into the opening of the mucous cells 


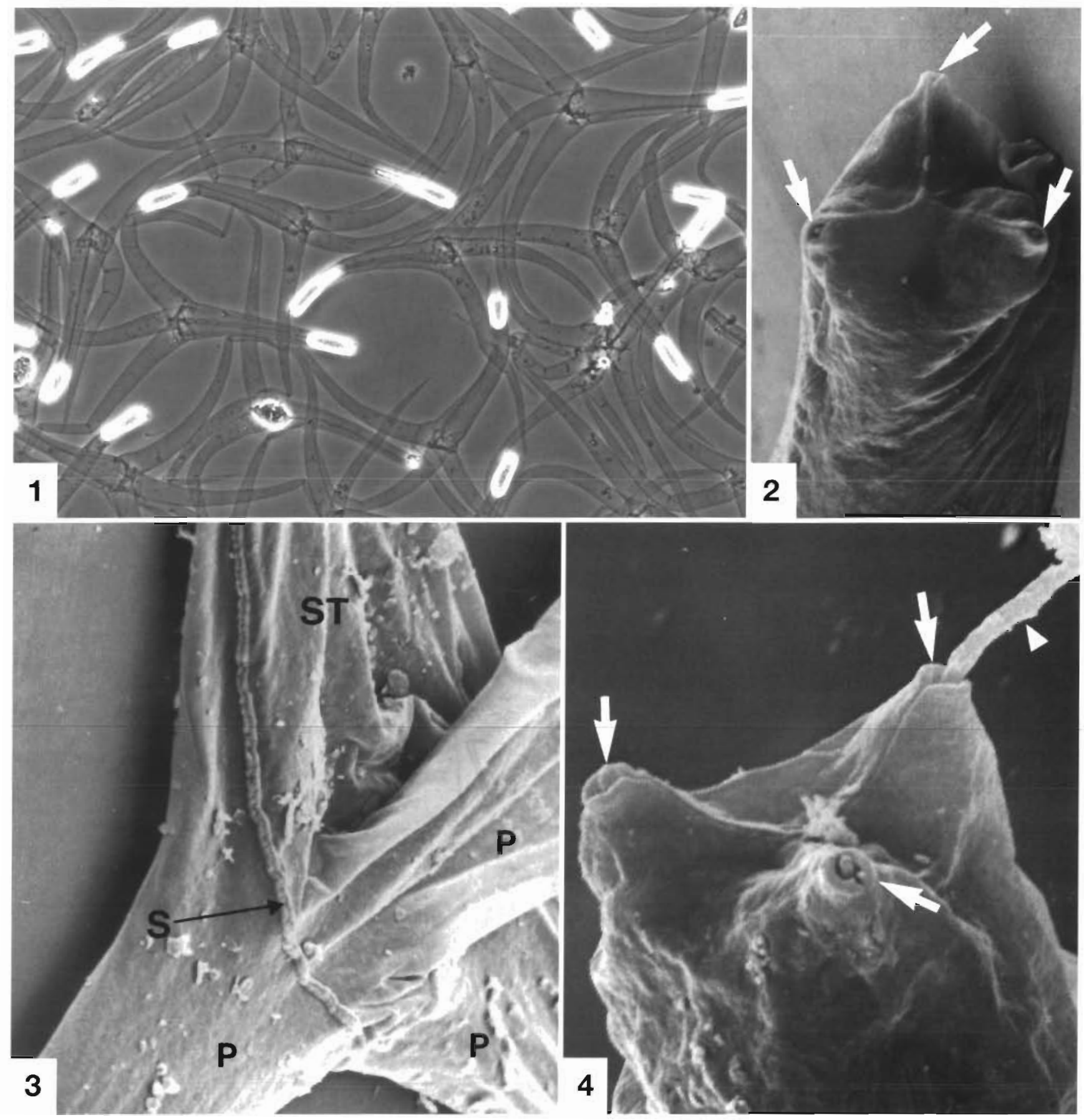

Figs. 1 to 4. Fig. 1. Mature waterborne triactinomyxon spores released from infected Tubifex tubifex, 120 d post exposure (p.e.), fresh mount, $260 \times$. Fig. 2. Apical region of waterborne triactinomyxon spore. Note the 3 sutures of the shell valves leave 3 apertures where the tips of the 3 polar capsules are visible (arrows). Scanning electron micrograph (SEM), 5000x. Fig. 3. Part in the branching area of the style of a triactinomyxon spore. ST: style; P: processes of shell valves; S: suture. SEM, 5000x. Fig. 4. Apical region of waterborne triactinomyxon spore showing the 3 apertures of the shell valves (arrows) and extruded polar filament (arrowhead). SEM, 8300x

as well as into the surrounding epidermis. Most of the attached spores had penetrated the opening of the mucous cells with their apical ends to a depth of 1 to $2 \mu \mathrm{m}$ so that the tips of the polar capsules as well as the polar filaments, which had been extruded, were no longer visible (Fig. 12). In some cases injections of 1 or even 2 of the extruded polar filaments failed to reach their destination. These were either wound around the 

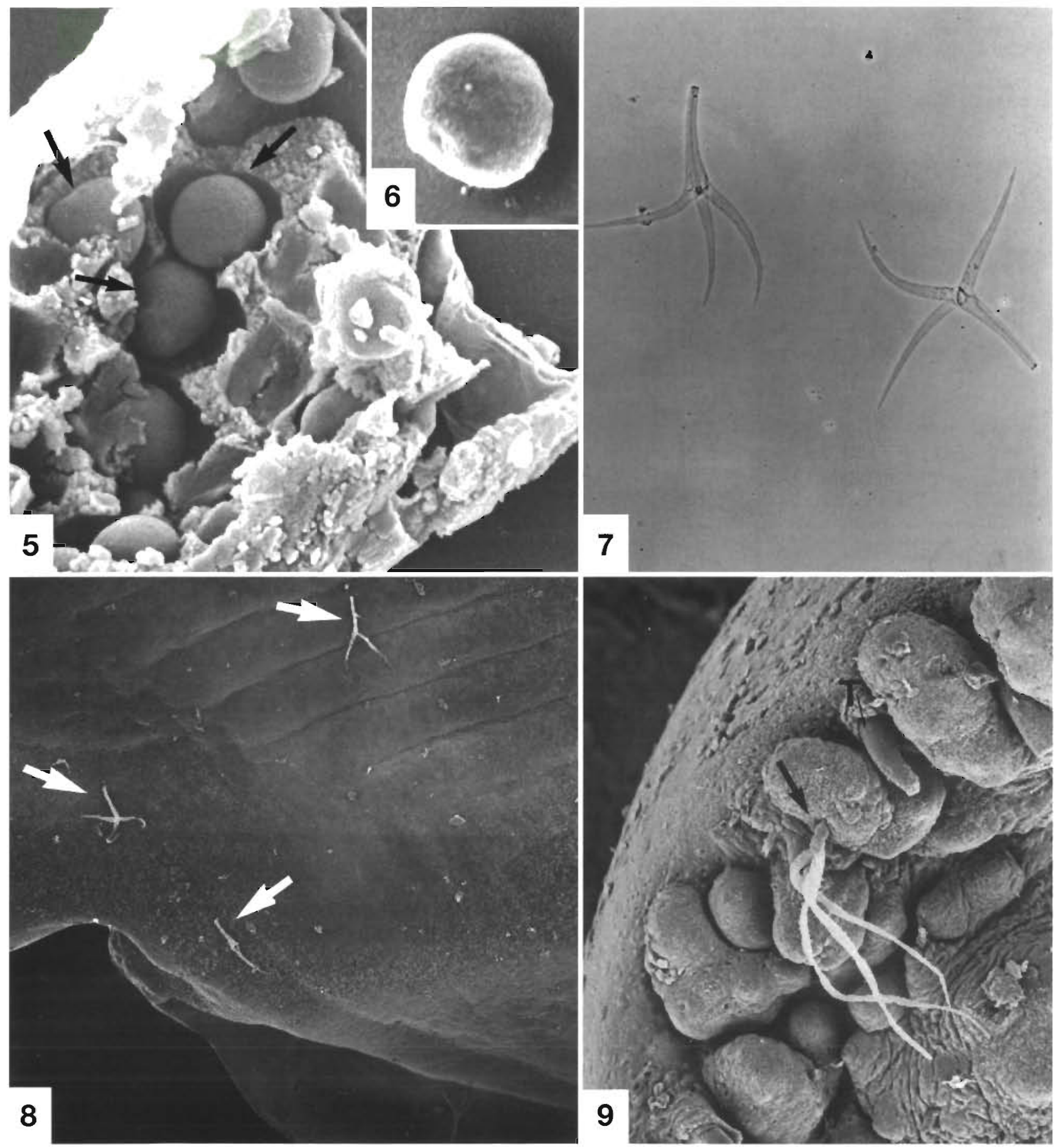

Figs. 5 to 9. Fig. 5 . Broken style in region of sporoplasm. Note the sporoplasm cells (arrows) which are embedded in cytoplasm of sporoplasm somatic cell. SEM, 6800×. Fig. 6. Separated sporoplasm cell of a triactinomyxon spore. SEM, 10000x. Fig. 7. Empty spore shells of waterborne triactinomyxon spores, 30 min p.e. of rainbow trout fry. Unstained fresh preparation, 150x. Fig. 8 . View of the interaction between triactinomyxon spores and rainbow trout fry. Three triactinomyxon spores (arrows) attached to pectoral fin, 1 min p.e. SEM, 55x. Fig. 9. Penetration by a triactinomyxon spore (arrow) of upper jaw between the teeth (T), 1 min p.e. SEM, 200x

tips of the polar capsules or stretched along the bodies of the fish (Fig. 14). In these cases the triactinomyxons were only attached by means of 1 or 2 polar filaments that had penetrated the epidermis.
After 1 min post exposure, spore shells were opened at the apical end along the 3 sutural ridges. In some cases 1 of the 3 sutures on the side of the style was torn over $15 \mu \mathrm{m}$, such that the sporoplasm germs, which had 


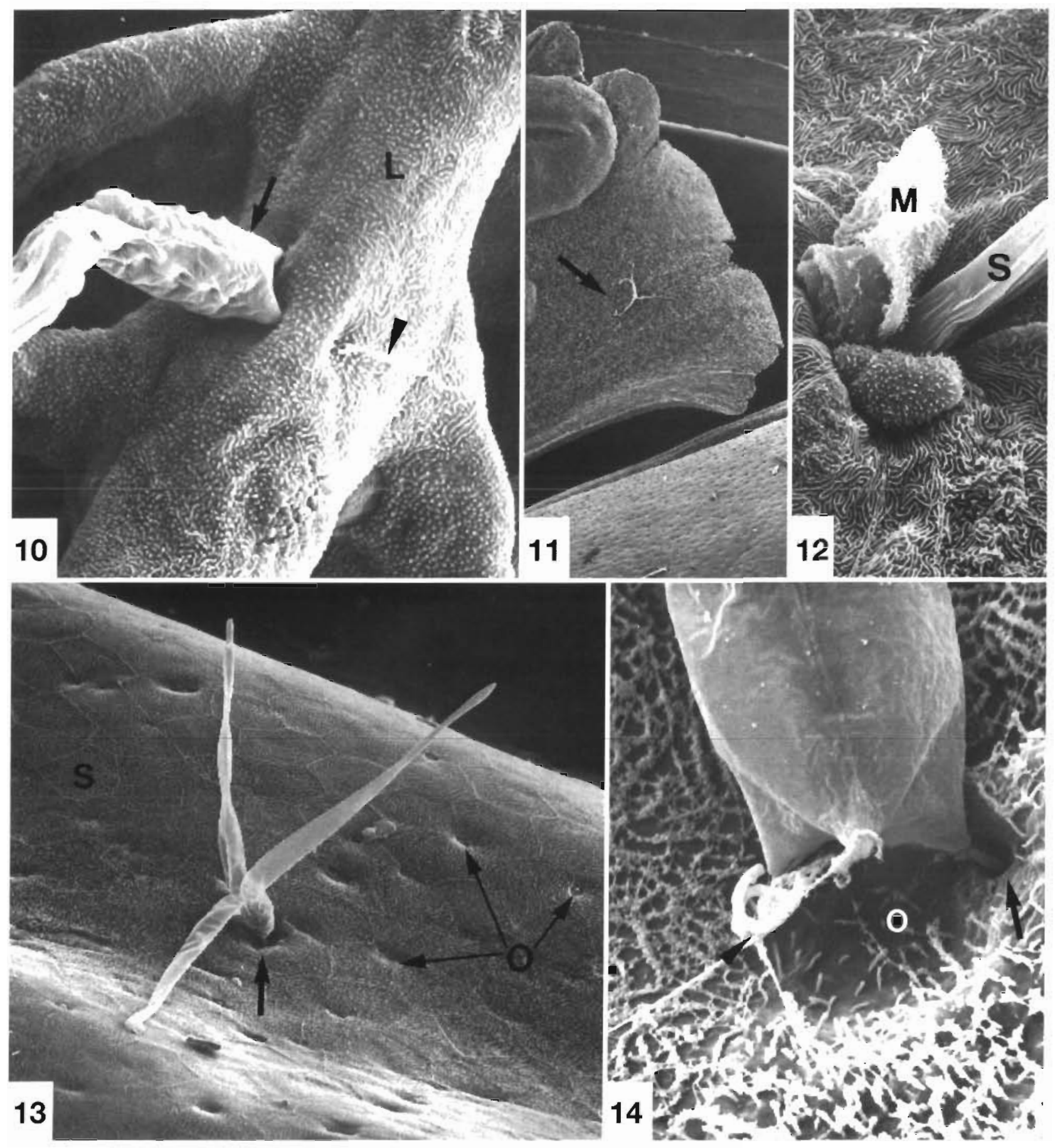

Figs. 10 to 14. Fig. 10. Penetration by a triactinomyxon spore (arrow) of primary lamellae (L) of gill. Note the penetration of polar filament through lamellae (arrowhead), 1 min p.e. SEM, 200x. Fig. 11. Triactinomyxon spore attached to adipose fin (arrow), 1 min p.e. SEM, 50x. Fig. 12. Higher magnification of Fig. 10 showing the deep penetration by apical part of triactinomyxon spore with the 3 polar capsules of the secretion opening of epidermis mucous cell. S: style; M: mucus. SEM, 1500x. Fig. 13. Triactinomyxon spore (arrow) attached with the extruded polar filament to epidermis surrounding the opening of a mucous cell, 1 min p.e S: skin epidermis of abdominal side; O: secretion openings of mucous cells. SEM, 500x. Fig. 14. Triactinomyxon spore attached to epidermis. Note that only 1 extruded polar filament is injected into epidermis (arrow); the second one failed to penetrate epidermis (arrowhead); the third polar filament is still not extruded, 1 min p.e. O: secretion opening of mucous cell. SEM, 5000 $\times$ 

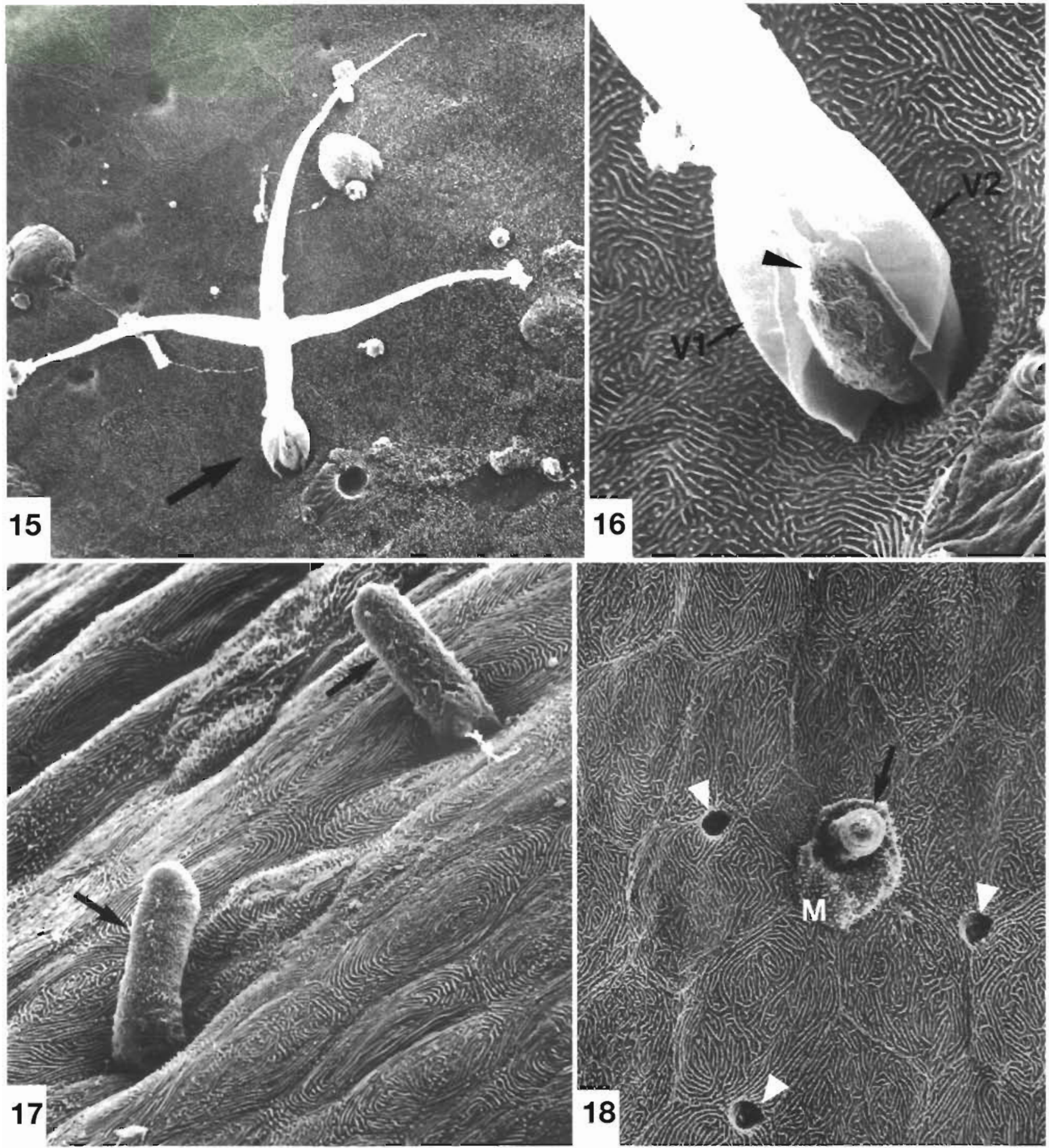

Figs. 15 to 18. Fig. 15. Triactinomyxon spore (arrow) attached to secretion opening of a mucous cell in dorsal fin, 1 min p.e. SEM, 450×. Fig. 16. Higher magnification of a part of Fig. 15 showing penetration by triactinomyxon sporoplasm of secretion opening of mucous cell, $1 \mathrm{~min}$ p.e. One of the suture edges between 2 valves (V1 and V2) is open. Note fibrous structure surrounding sporoplasm (arrowhead). SEM, 2000×. Fig. 17. Penetration by 2 triactinomyxon sporoplasm cells (arrows) of dorsal fin after falling away of shell valves, 2 min p.e. SEM, 400x. Fig. 18. Deeper penetrated triactinomyxon (arrow) in the secretion opening of a mucous cell. Arrowheads indicate the secretion openings of other mucous cells (M: mucus) 4 min p.e. SEM, 1000x

penetrated the openings of the mucous cells, were visible (Figs. $15 \& 16$ ). The surface of this part of the sporoplasm germs, which were still to be found be- tween the shell valves, was rough and folded in contrast to the shell surface. The shell valves appeared inflated. From 1 to 5 min post exposure, cylinder-shaped, 

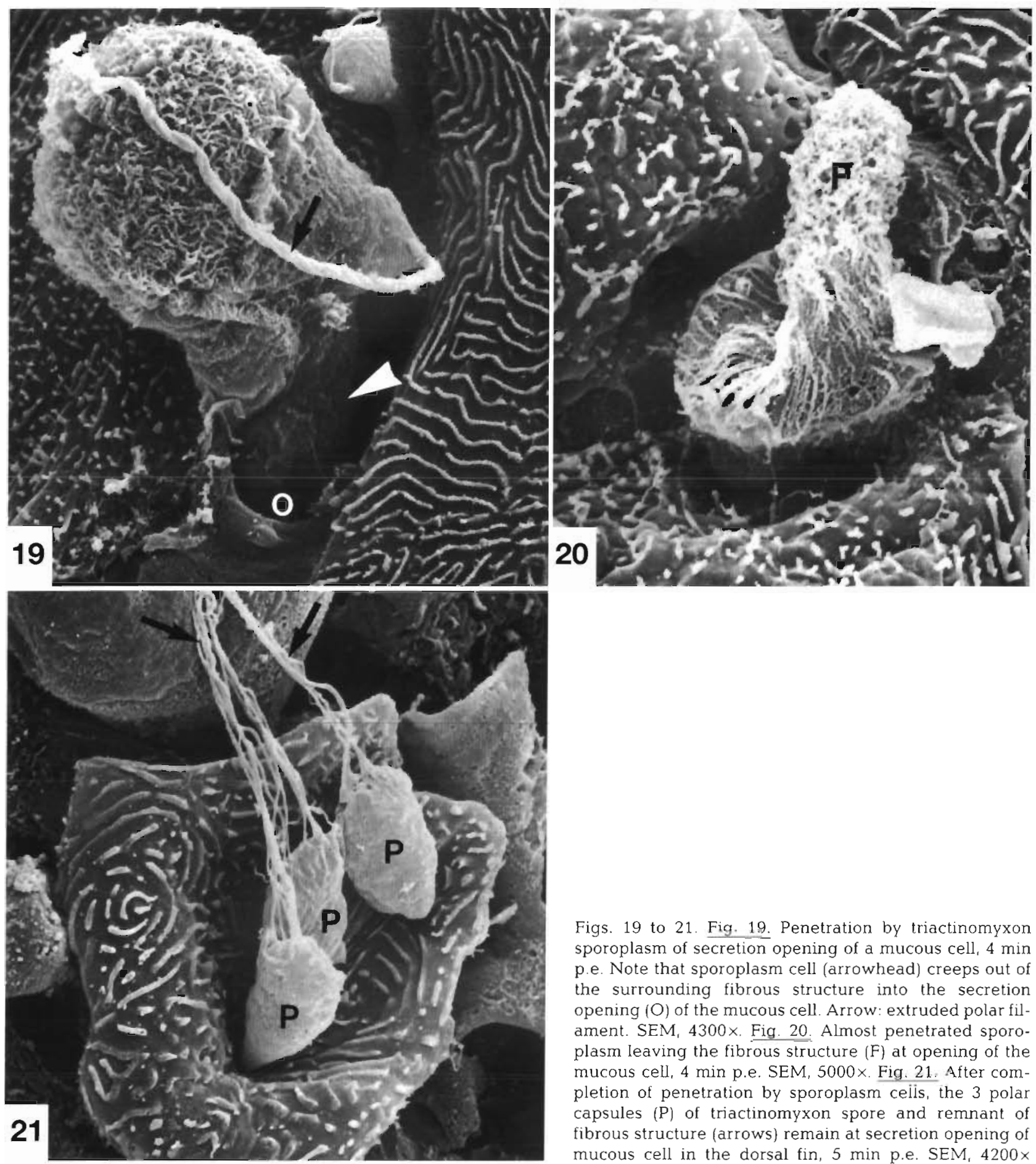

Figs. 19 to 21. Fig. 19. Penetration by triactinomyxon sporoplasm of secretion opening of a mucous cell, 4 min p.e. Note that sporoplasm cell (arrowhead) creeps out of the surrounding fibrous structure into the secretion opening $(\mathrm{O})$ of the mucous cell. Arrow: extruded polar filament. SEM, 4300x. Fig. 20. Almost penetrated sporoplasm leaving the fibrous structure $(F)$ at opening of the mucous cell, 4 min p.e. SEM, 5000x. Fig. 21. After completion of penetration by sporoplasm cells, the 3 polar capsules $(P)$ of triactinomyxon spore and remnant of fibrous structure (arrows) remain at secretion opening of mucous cell in the dorsal fin, 5 min p.e. SEM, $4200 \times$

compact sporoplasm germs together with the extruded polar capsules were found on the fins (Fig. 17), on the body surface, in the buccal cavity and on the respiratory epithelia. These were no longer surrounded by spore shells; rather they were covered by a fibrous tissue and were anchored to the fish epidermis by means of the extruded polar filaments. The sporoplasm germs which were just beginning to penetrate the openings of the mucous cells, as well as those that had not yet penetrated, had a length of $25 \pm 0.7 \mathrm{~mm}$ and a width of $9 \pm 0.2 \mu \mathrm{m}$. Sequentially, the sporoplasm germs migrated step by step out of the surrounding fibrillary structure into the epidermis (Figs. 18, $19 \& 20$ ). The fibrous structure that was left behind was compressed 

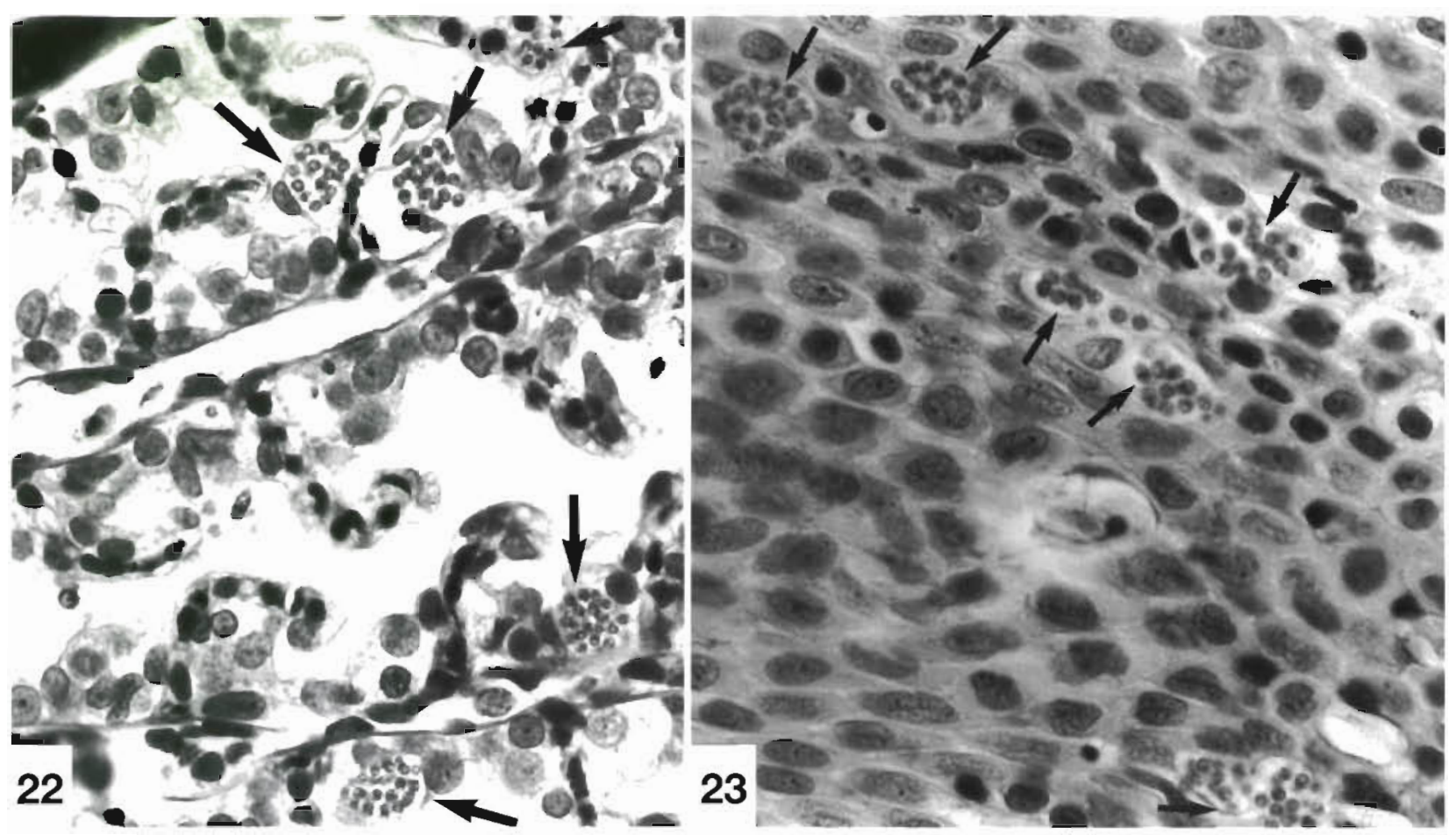

Figs. 22 \& 23. Fig. 22. Penetrated triactinomyxon sporoplasm cells (arrows) in gill epithelial cells, 30 min p.e. H\&E, 500x Fig. 23. Penetrated triactinomyxon sporoplasm cells (arrows) in the epidermis of caudal fin, 30 min p.e. H\&E, 500X

and had a rough surface with string-like structures. Subsequently, after all sporoplasm germs had infiltrated the fish tissue, the 3 polar capsules and the fibrous structure remained behind at the openings of the mucous cells (Fig. 21). All steps of the interaction between the triactinomyxon spores and rainbow trout fry, from the extrusion of the polar filaments to the penetration of all sporoplasm germs, could be observed after the first minute for up to $1 \mathrm{~h}$ post exposure.

\section{Host specificity of the triactinomyxon spores of Myxobolus cerebralis}

Trial 1

The irritated behavior of the rainbow trout fry described above was also observed in the rainbow trout species in this experiment, but was absent in all 3 cyprinid fish. The histological examination of rainbow trout fry taken 10,20 , and 30 min post exposure to the triactinomyxon spores revealed aggregates of sporoplasm cells lying intercellularly in the gill epithelial cells (Fig. 22) and in the entire epidermis, especially concentrated in the fins (Fig. 23). The same examination of the epidermis and gills of carp, goldfish and nose gave no evidence of penetration of the triactinomyxon spores of Myxobolus cerebralis.
Microscopic examinations of water from all 4 containers, $3 \mathrm{~h}$ post exposure after the fish were transferred to bigger aquaria, showed that about $60 \%$ of the triactinomyxon spores in the water which had contained rainbow trout fry had released sporoplasm cells. These consisted of spore shells without polar capsules and sporoplasin cells. In the water in which carp, goldfish and nose were exposed, about 25, 20 and 32\%, respectively, of the triactinomyxon spores contained neither sporoplasm cells nor polar capsules. Moreover, many naked sporoplasm cells were found free in filtered water from the last 3 containers.

Rainbow trout developed black tails and exhibited whirling movements at $62 \mathrm{~d}$ post exposure. Microscopically, as well as histologically, all survivor trout were found to be infected with Myxobolus cerebralis The histologic examination of all cyprinid fish showed no evidence of myxosporean infection. The results of these experiments are summarized in Table 1.

\section{Trial 2}

In this trial in all 3 repeated experiments, rainbow trout fry exposed to the triactinomyxon spores of Myxobolus cerebralis behaved in the same way as exposed rainbow trout in Trial 1. None of the guppies, medaka or tadpoles showed any abnormal swimming 
Table 1. Infection of rainbow trout, carp, goldfish and nose $(n=10$ for each species) with the triactinomyxon stages of $M y x o b o l u s$ cerebralis (dose $=10000$ ind $\left.^{-1}\right)_{\text {i }}$ experiment duration $=5 \mathrm{mo}$

\begin{tabular}{|c|c|c|c|c|c|c|c|c|}
\hline & \multirow{2}{*}{\multicolumn{3}{|c|}{$\begin{array}{l}\text { Penetration of triactinomyxon } \\
\text { sporoplasm (min post exposure) }\end{array}$}} & \multirow{3}{*}{$\begin{array}{c}\text { Morphologically changed } \\
\text { triactinomyxon } \\
\text { spores }(\%)\end{array}$} & \multicolumn{4}{|c|}{ Symptoms } \\
\hline & & & & & \multirow[t]{2}{*}{ Black tail } & \multirow{2}{*}{$\begin{array}{l}\text { Whirling } \\
\text { movernent }\end{array}$} & \multirow{2}{*}{$\begin{array}{l}\text { Myxobolus } \\
\text { cerebralis }\end{array}$} & \multirow[t]{2}{*}{ Mortality } \\
\hline & 10 & 20 & 30 & & & & & \\
\hline Rainbow trout & + & + & + & 60 & $4(57 \%)$ & $4(57 \%)$ & $4(57 \%)$ & $3(43 \%)$ \\
\hline Carp & - & - & - & 25 & - & - & - & - \\
\hline Goldfish & - & - & - & 20 & - & - & - & - \\
\hline Nose & - & - & - & 32 & - & - & - & - \\
\hline
\end{tabular}

behavior after their exposure to the triactinomyxon spores of $M$. cerebralis. The histological examination of medaka and tadpole did not show any penetration of the triactinomyxon sporoplasm. In 1 of 18 guppies, penetrated triactinomyxon sporoplasms could be detected in the epidermis $30 \mathrm{~min}$ post exposure. In histological sections of this fish, 24 sporoplasm cell aggregates were counted from the epidermis. In the kidney of this fish a moderate infection with Sphaerospora sp. was detected. In all other samples no evidence of penetrated sporoplasm cells were observed.

In histological sections from rainbow trout samples taken 2 and $24 \mathrm{~h}$ post exposure, a large number of sporoplasm cell aggregates (up to 120) were detectable in epidermis, gill and buccal cavity tissues. Presporogonic stages of the penetrated triactinomyxon sporoplasm were detected in the subcutis of rainbow trout fry taken $60 \mathrm{~h}$ post exposure.

\section{Interaction between the triactinomyxon of Myxobolus cerebralis and fish components}

After freshly collected triactinomyxon spores were transferred to the petri dishes containing the mucus prepared from rainbow trout fry, carp, goldfish and nose, as well as transferred to the tap water as a control, the number of triactinomyxon spores which had released their sporoplasm cells or extruded their polar filaments were counted after 3,6, and $9 \mathrm{~h}$ post exposure (Table 2). As shown in Table 2, the results of the control petri dish with triactinomyxon spores in tap water without mucus were similar to those containing mucous from all 4 fish species used. The examination of the histological sections from the exposed fins of all 4 species did not show any penetration of the triactinomyxon sporoplasm cells. Either none or just a very few triactinomyxon sporoplasm were observed in fish freshly killed (by either method), while control live fish exposed to the same number of tri- actinomyxon had abundant forms present in the epidermis and in the gills.

\section{DISCUSSION}

The results of the scanning electron microscopic studies demonstrate for the first time the process of the interaction between the triactinomyxon spores of Myxobolus cerebralis and rainbow trout fry. As early as 1 min post exposure, the triactinomyxon spores were easily seen attached over the entire epidermis, the buccal cavity, and the respiratory epithelial cells of the gills. On these fish body regions the triactinomyxon spores selected the openings of the mucous cells as portals of entry. Moreover, the triactinomyxon spores extruded their polar filaments and injected them as an anchor directly into the mucous cell openings as well as into the surrounding epidermis cells. By this means the spores could attach to the body surface of the fish. We presume that extrusion of the polar filaments through the apical located openings between the 3 valves causes a disturbance of the pressure balance inside the style of the triactinomyxon spore. This may then result in an opening of the $Y$-shaped suture line between the extruded polar filaments. Simultaneously or immediately thereafter, the infectious sporoplasm germs migrate out between the 3 valves and penetrate the epidermis through the opening of the mucous cell. The empty shell of the triactinomyxon spore then detaches. However, the polar capsules together with the extruded polar filaments and the longitudinal

Table 2. Influence of prepared mucus from different fish species on the activation of the triactinomyxon stages of Myxobolus cerebralis

\begin{tabular}{|lccccc|}
\hline $\begin{array}{l}\text { Time post } \\
\text { exposure } \\
\text { (h) }\end{array}$ & $\begin{array}{c}\text { Morphologically changed triactinomyxon spores (\%) } \\
\text { Rainbow trout } \\
\text { mucus }\end{array}$ & $\begin{array}{c}\text { Carp } \\
\text { mucus }\end{array}$ & $\begin{array}{c}\text { Goldfish } \\
\text { mucus }\end{array}$ & $\begin{array}{c}\text { Nose } \\
\text { mucus }\end{array}$ & Tap water \\
\hline 3 & 7 & 5 & 8 & 6 & 6 \\
6 & 12 & 11 & 9 & 11 & 10 \\
9 & 14 & 13 & 11 & 14 & 11 \\
\hline
\end{tabular}


fibers, which enveloped the sporoplasm germs and originated from the capsulogenic cells, remain until the entire sporoplasm germ packet migrates out of the surrounding fibers and penetrates the opening of the mucous cell. The long fibers which envelope the sporoplasm germ packet have also been seen by transmission electron microscopy (El-Matbouli \& Hoffmann 1998).

The convulsive backward movements of the trout fry during their exposure to the triactinomyxon spores are attributed to the injection of the polar filaments into the epidermis and the penetration of the sporoplasm germs into the openings of the mucous cells. The irritation, particularly in the respiratory epithelial cells, was most probably the reason for the observed jerking and swimming behavior of the exposed trout.

Whereas no studies on the host specificity of actinosporeans have been conducted, several reports about Myxosporea exist (Kudo 1920, Dyková \& Lom 1982, El-Matbouli et al. 1992). The results of the transmission experiments in our study demonstrated that the triactinomyxon spores of Myxobolus cerebralis reacted specifically with rainbow trout, penetrating their epidermis and eventually causing whirling disease (see Table 1). The histological study of all exposed individuals in Trials 1 and 2 (rainbow trout, carp, goldfish, nose, guppy, medaka and tadpoles) revealed aggregates of penetrated sporoplasm germs of triactinomyxons only in the epidermis or gills of rainbow trout fry. In addition, the number of the empty triactinomyxon shells in the water where rainbow trout were exposed was significantly higher $(60 \%)$ than in the other 3 containers $(25,20$, and $32 \%)$. The naked sporoplasmpackets found free in the water of all containers in which the cyprinid fish were exposed most probably indicated that mechanical effects caused by the swimming movements of the fish had caused actinosporeans to activate.

The number of triactinomyxon spores showing morphological changes (with regard to their sporoplasm and polar capsules) after exposure to the mucus of all 3 cyprinid fish, as well as mucus of rainbow trout, did not show significant differences from those in the control exposure (see Table 2). Moreover, there was no evidence of penetrated triactinomyxon sporoplasm germs in histological sections of the separated fins of rainbow trout fry exposed for $3 \mathrm{~h}$ to the spores.

With rare exception, the actinosporean stages of Myxobolus cerebralis showed a high specificity for rainbow trout. In Trial 2, 1 guppy was found to contain penetrated sporoplasm cells, clearly indicating that the actinosporeans had attached and delivered the cells into the epidermis. We are uncertain why this 1 particular guppy responded to invasion while the others did not and whether the underlying infection with
Sphaerospora sp. somehow contributed to the result observed. It may be that a combination of both the mechanical and chemical (and perhaps other) stimuli allows, particularly at extremely high exposure rates, a few actinosporeans to invade non-salmonid hosts. Additional studies to determine which factors are the most important in controlling the specificity of the response to invasion are needed, and these may aid in explaining how, on occasion, other fish species are recognized by the actinosporeans of $M$. cerebralis.

According to Yokoyama et al. (1995) the actinosporean stage (raabeia) of Myxobolus cultus reacted nonspecifically with prepared mucus from either the fish host (goldfish) or other fish species such as carp, rainbow trout, catfish Ictalurus punctatus and Japanese eel Anguilla japonica.

The nonspecific reaction of the actinosporean stage of Myxobolus cultus could not be confirmed for the triactinomyxon spores of $M$. cerebralis, which reacted only with salmonid fish. Moreover, the presence of mucus alone or even parts of the host fish failed to influence the triactinomyxon spores of $M$. cerebralis. Our results suggest that both a mechanostimulant, represented by the movement of the fins and swimming of the fish host, and a chemoreceptor, probably located only on the body surface of salmonid fish, are required for attachment and penetration of triactinomyxon spores and their sporoplasm germs.

Cnidarians such as hydra have dischargeable nematocysts morphologically similar to actinosporean and myxosporean polar capsules (Lom \& Puytorac 1965). In contrast to the polar capsules of the phylum Myxozoa, the process and the mechanisms which influence the extrusion of nematocysts have been investigated well (Tardent 1995). As early as 50 yr ago, Pantin (1942) reported that the extrusion of the nematocysts of the sea anemone Anemonia sulcata required not only the mechanical contact with prey, but also chemical stimuli.

Infectious stages of other parasite groups such as trematodes also require both mechanical and chemical stimuli. Ratanarata-Brockelman (1974) reported that the vibrational frequencies caused by the fin movements of the fish host stimulated the cercaria of Diplostomum spathaceum. Ferguson (1943) also found that the cercaria of Diplostomum spp. possessed a well-developed thighmotropy. However, both authors suggested that chemotactic mechanisms were essential in the finding of the fish hosts by the cercaria,

In conclusion, the results of this work could demonstrate that the triactinomyxon spores of Myxobolus cerebralis are family specific and penetrate only in salmonid fish. The portals of entry are the secretory openings of the mucous cells in the epidermis, buccal cavity, and gill regions. Furthermore, the results give evidence that the triactinomyxon spores of $M$. cere- 
bralis may require both mechanical (vibrational frequencies) and chemical stimulation for locating and attaching to the salmonid fish host. Cytochemical as well as biophysical studies are required to clarify these factors.

Acknowledgements. Part of this work was supported by funding obtained from the U.S. Fish and Wildlife Service, the Whirling Disease Foundation and Trout Unlimited.

\section{LITERATURE CITED}

Dyková I, Lom J (1982) Sphaerospora renicola n.sp., a myxosporean from carp kidney, and its pathogenicity. Z Parasitenkd 68:259-268

El-Matbouli M, Fischer-Scherl T, Hoffmann RW (1992) Present knowledge on the life cycle, taxonomy, pathology and therapy of some Myxosporea spp. important for freshwater fish--a review. Annu Rev Fish Dis 2:367-402

El-Matbouli M, Hoffmann RW (1991) Effect of freezing, aging and passage through the alimentary canal of predatory animals on the viability of Myxobolus cerebralis spores. $\mathrm{J}$ Aquat Anim Health 3:260-262

El-Matbouli M, Hoffmann RW (1998) Light and electron microscopic study on the chronological development of Myxobolus cerebralis in Tubifex tubifex to the actinosporean stage triactinomyxon. Int J Parasitol 28:195-217

El-Matbouli M, Hoffmann RW, Mandok C (1995) Light and electron microscopic observations on the route of the tri-

Editorial responsibility: Wolfgang Körting,

Hannover, Germany actinomyxon-sporoplasm of Myxobolus cerebralis from epidermis into the rainbow trout (Oncorhynchus mykiss) cartilage. J Fish Biol 46:919-935

Ferguson MS (1943) Migration and localisation of an animal parasite within the host. J Exp Zool 93:375-399

Hedrick RP, El-Matbouli M, Adkison MA, MacConnell E (1998) Whirling disease: re-emergence in wild trout. Immunol Rev 166 (in press)

Hoffman GL (1990) Myxobolus cerebralis, a worldwide cause of salmonid whirling disease. $J$ Aquat Anim Health 2 $30-37$

Kudo R (1920) Studies on Myxosporidia. A synopsis of genera and species of Myxosporidia. Ill Biol Monogr 5:1-265

Lom J, Puytorac PD (1965) Studies on the myxosporidian ultrastructure and polar capsule development. Protistologica 1:53-65

Markiw ME (1989) Portal of entry for salmonid whirling disease in rainbow trout. Dis Aquat Org 6:7-10

Nehring RB, Walker PG (1996) Whirling disease in the wild: the new reality in the intermountain west. Fisheries (Bethesda) 21:28-32

Pantin CFA (1942) The excistation of nematocysts. J Exp Biol 19:294-310

Ratanarata-Brockelman C (1974) Migration of Diplostomum spathaceum (Trematoda) in the fish intermediate host. Z Parasitenkd 43:123-134

Tardent P (1995) The cnidarian cnidocyte, a high-tech cellular weaponry. Bioessays 17:351-362

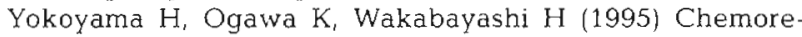
sponse of actinosporean spores of Myxobolus cultus to skin mucous of goldfish Carassius auratus. Dis Aquat Org $21: 7-11$

Submitted: May 19, 1998; Accepted: August 31, 1998

Proofs received from author(s): December 8, 1998 